\title{
Influence of the Grazing Conditions on the Floristic Diversity in the South Eastern part of the Gutai Mountains, the Maramures County
}

\author{
Zorica VOŞGAN ${ }^{1 *}$, Roxana VIDICAN ${ }^{2}$, Lucia MIHALESCU ${ }^{1}$, Monica MARIAN ${ }^{1}$, Stela JELEA ${ }^{1}$, Oana MARE \\ ROSCA$^{1}$, Anca DUMUȚA ${ }^{1}$, Susana SFECHIŞ ${ }^{2}$ \\ 1) Technical University of Cluj-Napoca, North University Center of Baia Mare, no.76 Victoriei Street, \\ Romania \\ 2) University of Agricultural Sciences and Veterinary Medicine, Cluj-Napoca, Romania \\ *Corresponding author: zori_v13@yahoo.com
}

Bulletin USAMV series Agriculture 72(2)/2015

Print ISSN 1843-5246; Electronic ISSN 1843-5386

DOI 10.15835/buasvmcn-agr: 11390

\begin{abstract}
Phytosociological studies have been carried out to estimate species richness and species diversity in area where shepherding is an ancient custom. Our research has been conducted on the Gutai Mountains meadows, on an area of 130 hectares, aiming to monitor the diversity of plant species and the pastoral value of the grazing lands, used to feed the animals. Data processing was done based on botanical sampling, the pastoral value has been calculated, and the diversity has been estimated with the Shannon $\left(\mathrm{H}^{\prime}\right)$. Thus, we have observed that after annual grazing, and lack of the pasture improvement measures, the floristic diversity suffers. Values Shannon index ( $\left.\mathrm{H}^{\prime}\right)$ are between 1.17 and 2.63, as the meadows is being invaded by low forage value species (eg. Nardus stricta) that occupy a considerable area. The pastoral value of the pasture was also calculated, that was of 0.85 points; this low value being influenced by overgrazing, soil compaction, tendency of invasive plants with low nutritional value. The influence of uncontrolled grazing on mountain pasture results in a decrease in pasture productivity due to reduced diversity of grassy carpet, where acidophilus species have appeared, and weeds have invaded the grazing land area. It is well to remember that the long-term exerted anthropogenic pressure on grasslands affects the ecosystem diversity.
\end{abstract}

Keywords: diversity, grazing, pastoral value, Shannon index.

\section{INTRODUCTION}

Agricultural biodiversity has an intrinsic value, as it provides the support system of life and the development of the socio-economic systems. The influence of agricultural practices on the plants diversity has been extensively studied in the natural ecosystems (Cristea et al., 2004). The reality is different when we speak about the Gutai Mountains natural pastures - a region which is year by year exploited by grazing. Therefore it is necessary to conduct the phytosociological studies to understand the current status of vegetation, species richness, diversity, explain or predict its pattern, relationships, classification and distribution of plant communities for proper planning and conservation (Jayakumar et al., 2002; Ilorkar and Khatri, 2003; Krishna et al., 2014 ).

\section{AIMS AND OBJECTIVES}

In this survey, we have pointed to the floristic diversity in the South Eastern part of the Gutai Mountains, where the annual small ruminant 
grazing in extensive system occurs. The objectives of this study consisted in the calculation of the diversity index and the pastoral value of meadows.

\section{MATERIALS AND METHODS}

This research was conducted for a period of three years in the South Eastern part of the Gutai Mountains at an altitude of $1000-1300 \mathrm{~m}$. The plants species diversity was calculated using the Shannon index $\left(\mathrm{H}^{\prime}\right)$ (1948). After the vegetation bonitation, the pastoral value was calculated according to the Practical Guide Rotar et al., (2009).

\section{RESULTS AND DISCUSSION}

When we are referring to the pastoral value we consider the vegetation biodiversity too, because the structure of the vegetation cover (respectively the presence of some certain species) is influencing the pastoral value (Sărăteanu et al., 2008).

To analyze the floristic diversity in the South Eastern part of the Gutai Mountains, we made up observation cards which contain information on plant species, plant communities and plant associations observed and identified in the field. It was found that prevail acidophile phytocoenosis erected by Nardus strica - Viola declinata into which penetrate shrub species, such as: Vaccinium myrtillus, Vaccinium vitis-idaea. On compact soil grow the Deschampsia caespitosa which is a low value forage grass, and Festuca rubra which is a valuable forage grass is less frequent. In patches there are oligotrophic areas with various species of Sphagnum so., Carex sp., Drosera rotundifolia. Super used grazing lands are invaded by nytrophile vegetation, and weeds such as Urtica sp., Veratrum album, Rumex sp. make their appearance too.

The Shannon index values generally fit in between 1.5 and 3.5, and on the studied lawn the values of this parameter vary between 1.17 and 2.63. These values indicate that the floristic structure of the analyzed vegetation has a reduced diversity due to the aggressiveness of plant species such as Nardus stricta which are invading large surfaces.

After the main flora plant species growing on the analyzed meadows have been studied, we could calculate its pastoral value, taking into account that it is exploited by sheep and goats grazing, each year. The lack of maintenance in the permanent natural meadows from the Gutai Mountains is reflected in the presence of fallow mounds. The calculated pastoral value is low, 0.85 points; this low output is closely connected to the environment conditions of the studied mountainous zone and mostly to the human activities dedicated to his animals.

\section{CONCLUSION}

The analysis of the plants species diversity on an area of 130 ha denotes the presence of a pasture with low floristic diversity; there is a tendency to dominate by a single species, which will reduce local biodiversity. We have also found that the mountain meadow has a very low, subunitary pastoral value.

The lack of maintenance, the lack of a better animal load, and the pasture grazing period extended beyond the normal limits, caused the invaluable grassy vegetation invasion that affects the ecosystem biodiversity.

\section{REFERENCES}

1. Cristea V, Gafta D, Pedrotti F (2004). Phytosociology. University Press Cluj-Napoca.

2. Hari KP, Sudhakar RC, Meena SL, Katewa SS (2014). Pattern of plant species diversity in grasslands of Rajasthan. India Taiwania 59(2):111-118.

3. Ilorkar VM, Khatri PK (2003). Phytosociological Study of Navegaon National Park, Maharashtra. Indian Forester 129:377-387.

4. Jayakumar S, Arockiasamy DI, Britto SJ (2002). Forest type mapping and vegetation analysis in part of Kolli hills, Eastern ghats of Tamil Nadu. Trop. Ecol. 43:345-349.

5. Sărățeanu V, Moisuc A, Butnariu M (2008). Analysis of the influence of some invasive plants species on the pastoral value of western Romanian grasslands. Grassland Science in Europe Uppsala 13:162-164. 